DOI: https://doi.org/10.31392/NZ-npu-144.2019.06

УДК 378.004

Генсерук Г. Р.

\title{
ЦИФРОВА КОМПЕТЕНТНІСТЬ МАЙБУТНІХ УЧИТЕЛІВ: ЗАРУБІЖНИЙ ДОСВІД
}

У статті розглянуто різні підходи зарубіжних науковиів щзодо трактування поняття "иифрова компетентність" та визначення складових компонентів цииррової компетентності майбутніх фахівиів. Проведено аналіз останніх робіт науковиів із досліджуваної проблеми. Проаналізовано європейські стандарти визначення иифрової компетентності, рамку ицирової компетентності вчителя Digital Competence of Educators (DigCoтрEdu). У статті виокремлено підходи до опису складових рамки ичиррової компетентності учителів. Цифрова компетентність майбутніх учителів $\epsilon$ важсливою $і$ передбачає вміння логічно та системно використовувати цифрові технології. Вона сприяє успішності майбутнього фахівия, вирішенню різних завдань та формуванню його важсливих жстттєвих компетенцій.

Аналіз робіт зарубіжсих дослідників дозволяє зробити висновок про різні підходи щодо класифікаиії та опису видів циифрових компетенцій вчителя. Розроблені рамки ичифрових компетенцій різних країн переважно включають такі складові: застосування иифрових технологій у професійному педагогічному середовищі; володіння професійними навичками пошуку, створення і спільного використання циифрового освітнього контенту; застосування цииррових інструментів в навчанні і викладанні; володіння цифровими інструментами і стратегіями оцінки результатів навчання; використання иифрових інструментів для розиирення освітніх можливостей учнів; безпека при застосуванні иичррових технологій.

Ключові слова: компетентність, цифррова компетентність, ичифрові технологї, рамка ичиррової компетентності, модель.

Сьогодні цифрова компетентність учителів набуває широкого значення, оскільки цифрові ресурси та цифрові медіа займають вагоме місце у щоденній практиці вчителів.

Цифрова компетентність $€$ інтегрованою частиною професійного розвитку майбутніх учителів, оскільки вони, повинні навчитися максимально використовувати цифрові технології для викладання і навчання. У студентів в процесі навчання в закладах вищої освіти на основі наукових та емпіричних форм знань слід сфрормувати здатність розробляти інноваційні способи використання цифрових технології для удосконалення середовища навчання. Для вирішення цього завдання педагогічна освіта повинна забезпечувати розвиток цифрової компетентності студентів, яка буде мати вирішальне значення для фрормування їх креативного мислення та вирішення складних проблемних завдань.

Розвиток цифрової компетентності майбутніх учителів передбачає не тільки адаптацію своїх методів до цифровізації, але й розробку, дизайн і апробацію в дії цифрових інструментів відповідно до свого навчального середовища і діяльності, що сприятиме отриманню оптимальних результатів навчання.

Проблемі фрормування цифрової компетентності майбутніх учителів, їх підготовки до професійної діяльності з використанням засобів цифрових технологій присвячено багато досліджень українських науковців. 
Спостерігаються різні підходи щодо трактування поняття "цифрова компетентність". М. Жалдак, Н. Морзе, О. Спірін розглядають сутність цифрової культури майбутніх учителів $[3,4,6]$. Різні підходи щодо визначення цифрової компетентності та обґрунтування їі структури розглянуто у дослідженнях Г. Генсерук, Н. Морзе, Л. Пєтухова [2, 4, 5]. Аспекти використання цифрових технологій у закладах вищої освіти висвітлено у працях В. Бикова, О. Глазунової, М. Шишкіної [1].

Сьогодні поняття “цифрова компетентність" є також питанням дискусій багатьох зарубіжних вчених. Заслуговує на увагу зарубіжний досвід розвитку цифрової компетентності майбутніх учителів.

Метою статті $€$ вивчення зарубіжного досвіду обґрунтування різних підходів щодо трактування цифрової компетентності майбутніх фахівців та її структурних складових.

Аналіз літературних джерел показав, що існує значна кількість досліджень науковців, які намагалася окреслити різні визначення щодо трактування поняття цифрової компетентності та її вимірів. Вони варіюються від простих до доволі складних описів різних вимірів цифрової компетентності, які намагаються розглянути різні сфрери знань та вмінь.

За дослідженням Ferrari (2012) цифррова компетентність - це сукупність знань, умінь, навичок (включаючи здібності, стратегії, цінності та обізнаність), які необхідні при використанні ІКТ та цифррових медіа для виконання завдань; вирішення проблем; спілкування; керування інформацією; співпраці; створення та обміну контенту [9].

Норвезькі науковці Rokenes та Krumsvik (2014) відзначають, що цифрова компетентність передбачає широкий спектр навичок, включаючи когнітивні та емоційні навички, а також соціологічні знання щодо використання цифрових технологій [15]. Акцент на навичках критичного мислення, що $€$ ключовою частиною цієї компетентності також спостерігається в дослідженнях Instefjorda (2015), який виділяє критичне та рефрлексивне використання цифрових технологій у формуванні нових знань [12].

За дослідженням Європейського Парламенту цифррова компетентність передбачає впевнене та критичне використання технології інформаційного суспільства для роботи, дозвілля та спілкування. Вона спирається на базові навички в сфері IKT: використання комп'ютерів для отримання, оцінки, зберігання та обміну інформацією, а також спілкування в спільних мережах через Інтернет.

В багатьох дослідженнях часто зустрічається обґрунтування терміну “цифрова грамотність". Так австрійський вчений W. Ng пропонує трискладову модель цифрової грамотності, яка включає такі галузі: технічну, пізнавальну (здатність критично мислити) та соціально-емоційну (вміння відповідально користуватися Інтернетом, включаючи “Етикет”, захищати безпеку та конфіденційність особистості, визначати загрози та небезпеку (рис. 1) [17]. 


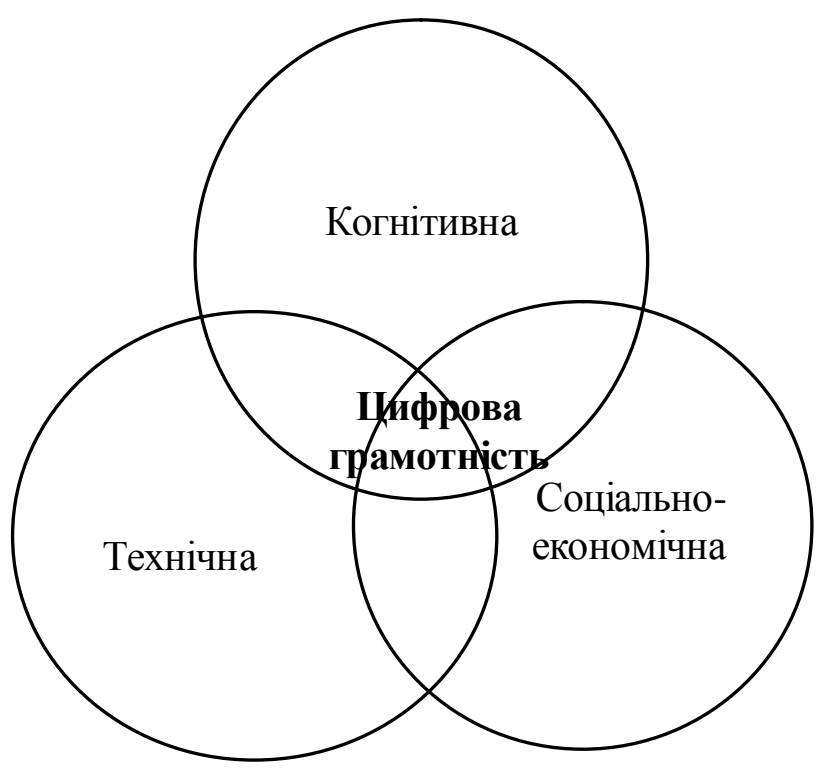

Рис. 1. Модель цฺифрової грамотності (Ng, 2012)

Автор виділяє такі основні навички, які має продемонструвати цифрровокомпетентна людина:

- вміння виконувати основні комп'ютерні операції та отримувати доступ до ресурсів для щоденного використання;

- пошук, виявлення та оцінка інформації, ефрективної для цілей дослідження та змісту навчання;

- вміння відбирати найбільш відповідні цифррові технології для виконання завдань, вирішення проблем та створення контенту;

- вміння поводитися належним чином в інтернет-спільнотах і захистити себе від загрози в цифррових умовах.

За дослідженням Erstada (2015) цифрова компетентність повинна включати такий набір компетенцій (табл. 1) [8].

Складові компетенції цифрової компетентності (Erstad, 2015)

В процесі дослідження нами проаналізовано проект Європейської комісії “Рамка цифрової компетентності для громадян" (DigComp), який $є$ важливим інструментом для підвищення рівня цифрової компетентності фрахівців у галузі освіти, підготовки та підвищення кваліфікації. Проект DigiComp (2013), фрінансований ЄС та спрямований на виявлення ключових компонентів цифрової компетентності та розробки загальної цифрової рамки компетенції.

Таблиця 1

\begin{tabular}{|l|l|}
\hline Основні навички & $\begin{array}{l}\text { прості навички користування комп’ютером та програмним } \\
\text { забезпеченням }\end{array}$ \\
\hline Завантаження & вміння завантажувати з Інтернету різні типи інформації \\
\hline Пошук & вміння отримати доступ до інформації \\
\hline Навігація & $\begin{array}{l}\text { вміння орієнтуватися в цифрових мережах, вивчаючи стратегії } \\
\text { використання Інтернету }\end{array}$ \\
\hline Класифікація & $\begin{array}{l}\text { вміння впорядковувати інформацію відповідно до певної } \\
\text { класифікаційної схеми чи жанру }\end{array}$ \\
\hline
\end{tabular}




\begin{tabular}{|l|l|}
\hline Інтеграція & вміння порівнювати та поєднувати різні типи інформації \\
\hline Оцінка & $\begin{array}{l}\text { вміння перевіряти та оцінювати інформацію, отриману в результаті } \\
\text { пошуку, критично аналізувати якість, актуальність, об'єктивність та } \\
\text { корисність знайденої інформації }\end{array}$ \\
\hline Співпраця & $\begin{array}{l}\text { вміти використовувати цифрові технології для співпраці та участі в } \\
\text { мережах. }\end{array}$ \\
\hline $\begin{array}{l}\text { Створення } \\
\text { контенту }\end{array}$ & $\begin{array}{l}\text { вміння представляти різні форми інформації використовуючи } \\
\text { конкретні інструменти та програмне забезпечення. }\end{array}$ \\
\hline
\end{tabular}

У проекті пропонується 5 ключових областей компетенції, а саме :

- інфоормація: ідентифрікація, отримання, зберігання, організація та аналіз цифрової інформації, її актуальність і цілі;

- комунікація: спілкування в цифрових середовищах, обмін ресурсами, онлайн-інструментами, співпраця за допомогою цифрових інструментів, взаємодія та участь у спільнотах та мережах, крос-культурної обізнаність;

- створення контенту: створення та редагування нового вмісту (від обробки тексту до зображень та відео); інтеграція та обробка наявних знань та змісту; створення власного творчого контенту, застосування інтелектуального права власності;

- безпека: особистий захист, захист даних, захист цифрової ідентичності, заходи безпеки;

- вирішення проблем: визначення цифррових потреб і ресурсів, прийняття обґрунтовані рішення про те, які цифррові інструменти $є$ найбільш придатними в залежності від мети, вирішувати концептуальні проблеми за допомогою цифрових засобів, вирішення технічних проблем, оновлення власних і інших компетенцій.

В процесі аналізу зарубіжного досвіду розвитку цифрової компетентності, нами виявлено багато досліджень щодо трактування та виміру цифрової компетентності вчителів. Багато науковців визначили аналогічні виміри цифрової компетентності для вчителів. На нашу думку варто виокремити рамки європейської DigiCompEdu (рис. 2), структура якої розроблена 3 DigiComp для громадян та моделі Mishra and Koehler's (2006) TPACK.

Рамка цифрової компетентності вчителів DigCompEdu включає 6 основних областей, у яких виражається компетентність вчителя (рис. 2).

Науковці Almerich i iн. (2016) виділяють дві великі підмножини для трактування структури цифрової компетентності для вчителів, що складаються з таких компетенцій [7]:

- технологічні компетенції;

- педагогічні компетенції. 


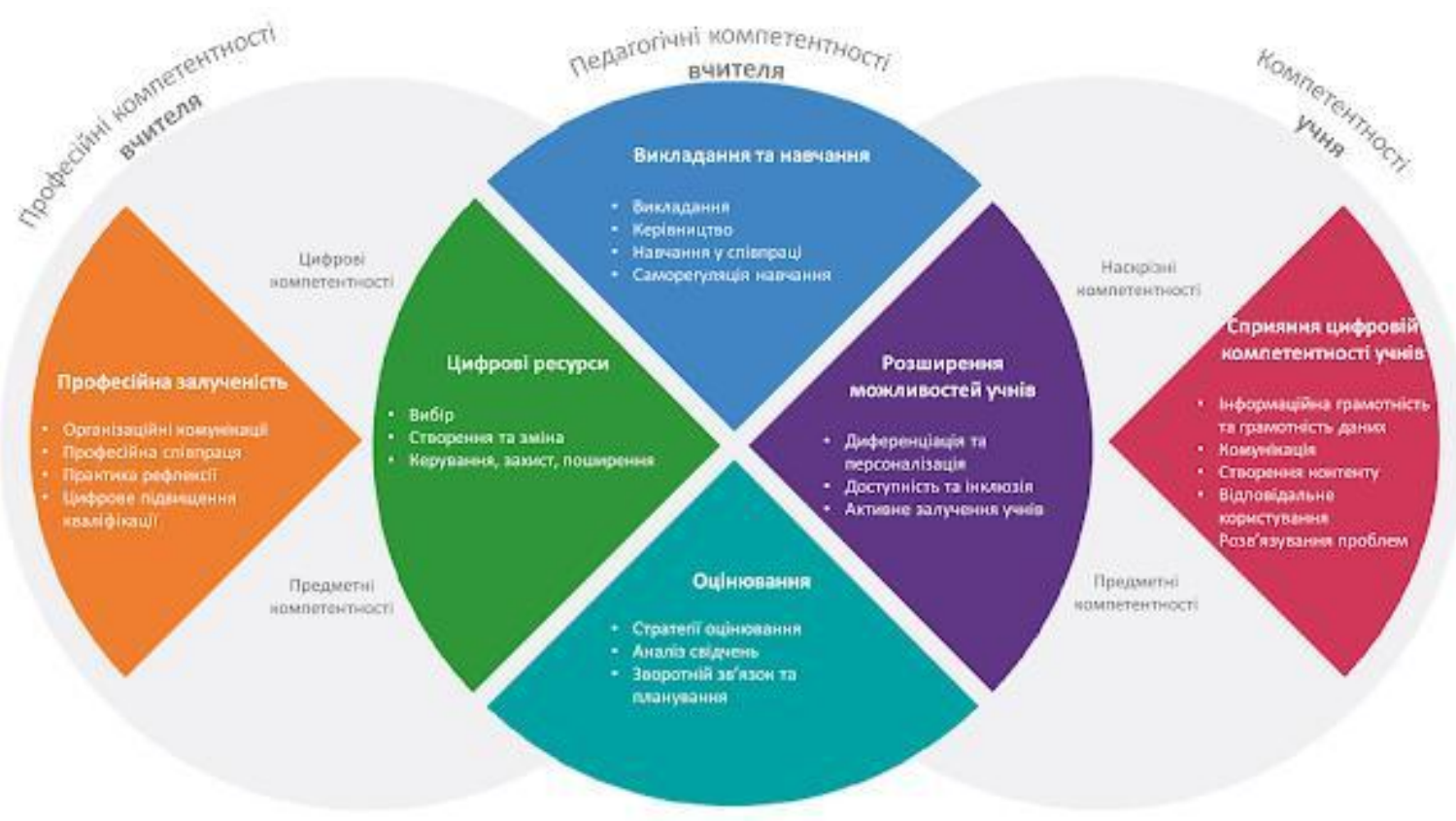

Puс. 2. Свропейська рамка для вчителів DigiCompEdu

Науковці Johannesen та ін (2014 року) пропонують структуру цифрової компетентності, яка включає в себе три аспекти. (рис. 3) [13].

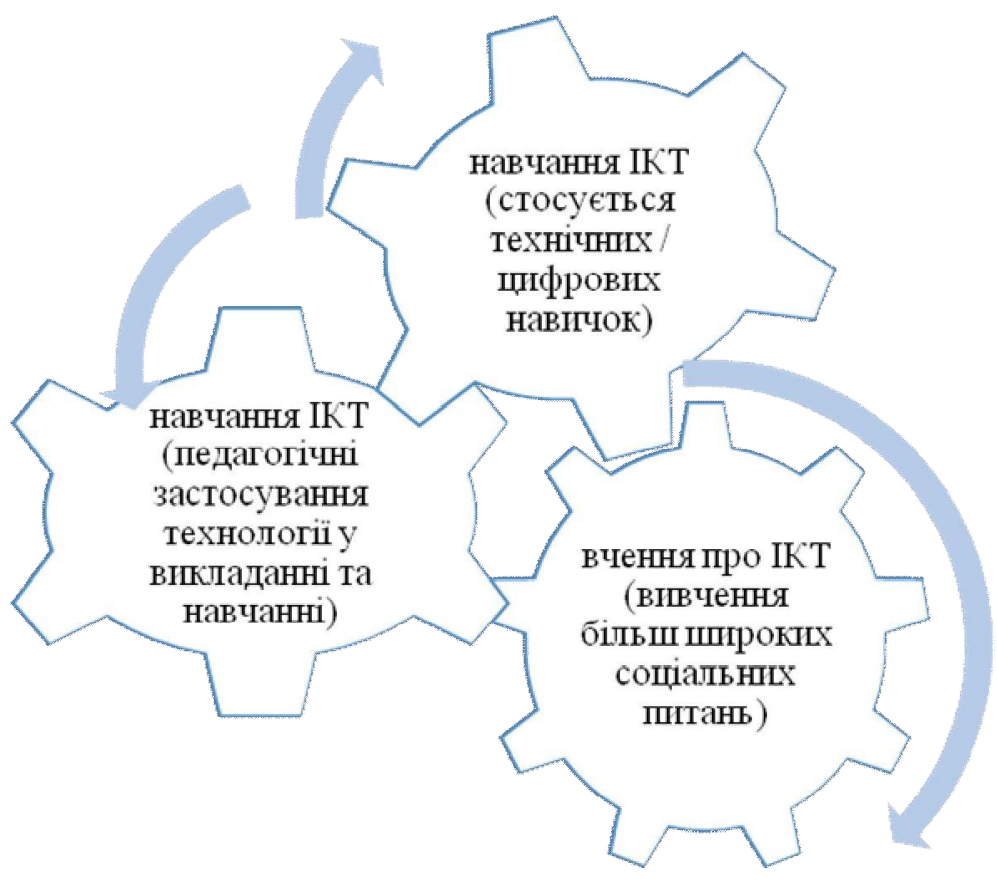

Рис. 3. Структура изифрової компетентності учителів (Johannеsеn, 2014)

Ці аспекти віддзеркалюють три виміри, висунуті науковцями Ottestad i iн (2014), а саме: загальна цифрова компетентність, дидактична цифрова компетентність та професійна-орієнтована цифрова компетентність [18].

Виміри цифррової компетентності описано також в дослідженні норвезьких науковців. Так Hatlevik (2017) пропонує трактування цифрової компетентності такої, яка містять чотири підкатегорії, а саме [10]: 
- пошук і процес;

- контент;

- цифррова відповідальність;

- зв'язок.

Lund та Erikson (2014) також наголошують на важливості технічних знань, однак, помітний акцент роблять на розумінні студентів процесів навчання 3 використанням цифрових технологій і конкретне застосування цифрового інструментарію для більш конкретних дисциплінарних практик і особливостей, що характеризують кожен окремий шкільний предмет [16].

llomaki та Paavola (2016) пропонують модель цифрової компетентності, яка включає такі чотири основні складові (рис. 4) [11].

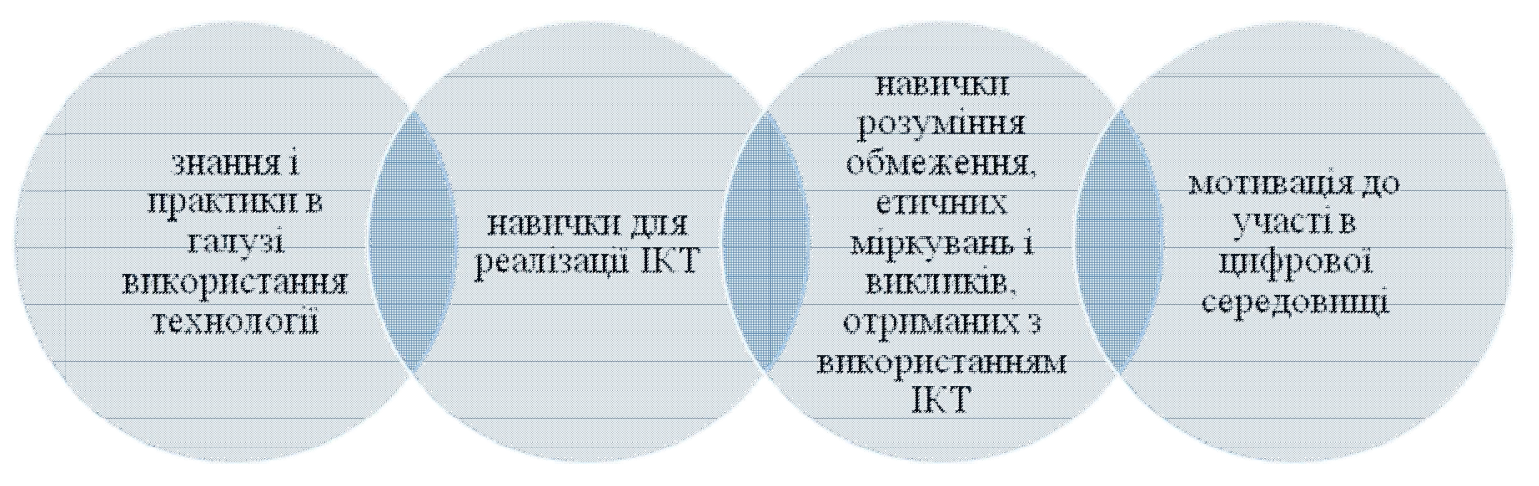

Рис. 4. Складові моделі циифрової компетентності (Ilomaki, 2016)

Ця модель відмінна, оскільки включає в себе мотивацію для участі в цифровому середовищі, що не згадується в інших проаналізованих дослідженнях. Остання модель відображає елементи моделі Mishra and Koehlers TPACK (2006), яка відображає можливості розширення цифрових технологій для навчання, для конкретних предметних галузей і дисциплін.

Відповідно до Рамки цифрової компетентності DigiCompEdu у різних країнах розроблено національні рамки цифрової компетентності для вчителів пов'язані з більш широкими професійними стандартами. Так, австралійські професійні стандарти для вчителів включають стандарти IКT для вчителів в двох аспектах:

- знання змісту і фрорм навчання з використанням цифрових технологій;

- створення та підтримка сприятливих і безпечних умов навчання 3 використанням цифрових технологій.

Норвезька рамка цифрової компетентності для вчителів, (Kelentric, 2017), розроблена норвезьким Центром ІКТ в освіті, також встановлюється в більш широких рамках на основі національних правил, керівних принципів програм педагогічної освіти, національних навчальних планів і національні рамок кваліфікацій (рис. 5) [14]. 


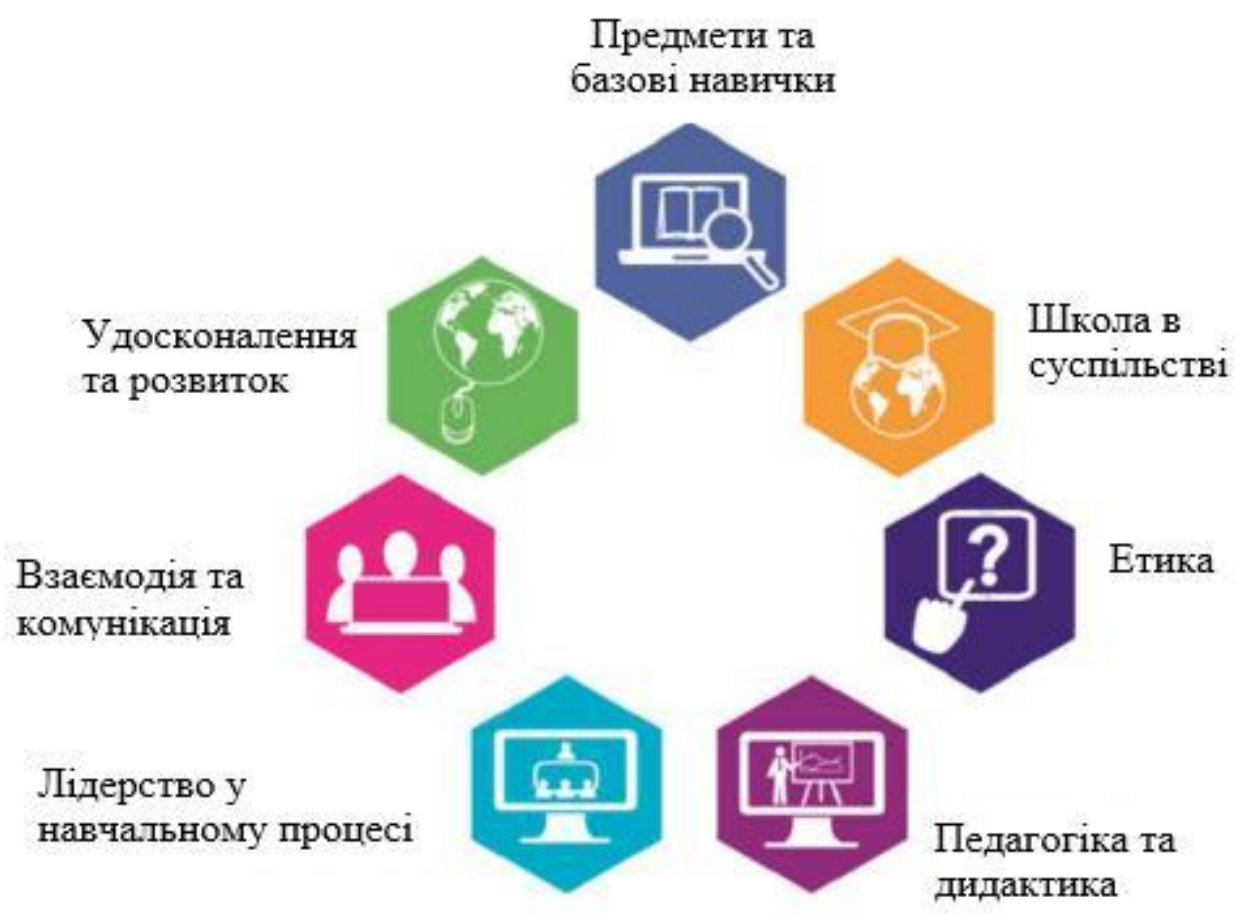

Рис. 5. Візуалізація складових рамки иฺифрової компетентності для вчителів Норвегії

Іспанська рамка цифрової компетентності вчителів спирається на рамки DigiComp ЄC, що відображає його 5 основних компетенцій (рис. 6).

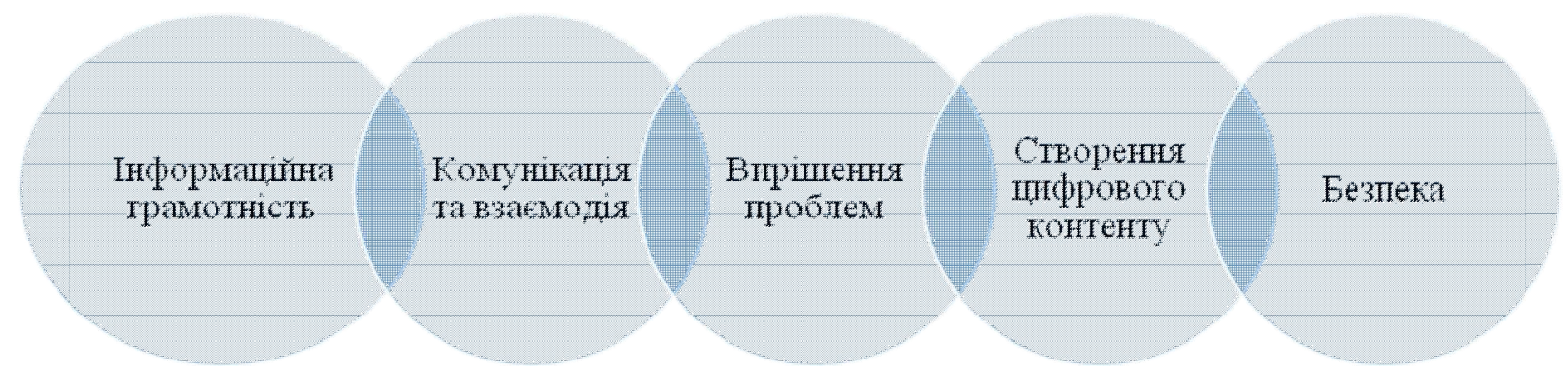

Рис 6. Рамка цุифрової компетентності для вчителів Іспанії

Аналіз досліджень показує, що різні моделі мають на меті охопити усі сторони та складові цифрової компетентності вчителів. Деякі моделі запропоновані дослідниками в цій галузі, інші з'являються відповідно до національних вимоги щодо рамок цифрової компетентності вчителів.

Висновок. Огляд вищезазначених моделей вказує на наявність різних трактувань компонентів цифрової компетентні. Спостерігається певний консенсус, однак залишається багато різних інтерпретацій стосовно того, що включає поняття "цифрова компетентність". В загальному, більшість рамок компетенцій зосереджені на технічних навичках, знаннях IКТ пов'язані з цим питанням, безпеці, створенні цифрового контенту.

Огляд зарубіжного досвіду в галузі розвитку цифрової компетентності вчителів показує, опис та структурування цифрових компетенцій вчителя, 
свідчить про розширення змісту його діяльності, зміну вимог до підготовки і умов професійного розвитку.

Перспективою подальших досліджень $є$ розробка, на основі вивченого досвіду трактування цифрової компетентності зарубіжними науковцями, інструментів для оцінювання та стратегії моделі розвитку цифрової компетентності вчителів учителів.

\section{Використана література:}

1. Биков В., Лещенко М. Цифрова гуманістична педагогіка відкритої освіти. Теорія і практика управління соціальними системами. № 4. С. 115-130. URL: http://nbuv.gov.ua/UJRN/Tipuss_ 2016_4_13

2. Генсерук Г. Цифрова компетентність як одна із професійно значущих компетентностей майбутніх учителів. Open educational e-environment of modern University, № 6. 2019. с. 8-16.

3. Жалдак М. І., Рамський Ю. С., Рафальська М. В. Модель системи соціально-професійних компетентностей вчителя інформатики. Науковий часопис Національного педагогічного університету імені М. П. Драгоманова. Серія 2. Комп’ютерно-орієнтовані системи навчання. № 7. 2009. с. 3-10.

4. Морзе Н. В. Інформатична компетентність учнів може бути вищою від компетентності тих, хто їх навчає? (за матеріалами моніторингового дослідження 3 інформатичних компетентностей випускників в Україні). Комп’ютер у школі та сім’ї. № 8. 2010. $\quad$ С. 3-8. $\quad$ URL: http://nbuv.gov.ua/UJRN/komp_2010_8_2

5. Пєтухова Л. Є. Теоретико-методичні засади формування інформатичних компетентностей майбутніх учителів початкових класів (автореф. дис. докт. пед. наук). URL: http://dspace.pdpu.edu.ua/bitstream/123456789/869/1/Петухова-.aref.pdf

6. Спірін О. М. Інформаційно-комунікаційні та інформатичні компетентності як компоненти системи професійно-спеціалізованих компетентностей вчителя інформатики. Інформаційні технології і засоби навчання. № 5 (13). 2009. URL: https://journal.iitta.gov.ua/index.php/itlt/ article/download/183/169

7. Almerich, G., Orellana, N., Suárez-Rodríguez, J., \& Díaz-García, I. (2016). Teachers' information and communication technology competences: A structural approach. Computers \& Education, 100, 110-125.

8. Erstad, O. (2015). Educating the Digital Generation. Nordic Journal of Digital Literacy, 5(01), 56-71.

9. Ferrari, A. (2012). DIGCOMP: A Framework for Developing and Understanding Digital Competence in Europe. Luxembourg: Publications Office of the European Union.

10. Hatlevik, O. E. (2017). Examining the Relationship between Teachers' Self-Efficacy, their Digital Competence, Strategies to Evaluate Information, and use of ICT at School. Scandinavian Journal of Educational Research, 61(5), 555-567.

11. Ilomaki, L., Paavola, S., Lakkala, M., \& Kantosalo, A. (2016). Digital competence-an emergent boundary concept for policy and educational research. Education and Information Technologies, 21(3), 655-679.

12. Instefjord, E. (2015). Appropriation of Digital Competence in Teacher Education. Nordic Journal of Digital Literacy, 9(04), 313-329.

13. Johannesen, M., Øgrim, L., \& Giæver, T. H. (2014). Notion in Motion: Teachers' Digital Competence. Nordic Journal of Digital Literacy, 9(04), 300-312.

14. Kelentrić, M., Helland, K. \& Arstorp, A. (2017) Professional digital competence framework for teachers. The Norwegian Centre for ICT in Education

15. Krumsvik, R. J. (2014). Teacher Educators' Digital Competence. Scandinavian Journal of Educational Research, 58(3), 269-280.

16. Lund, A. \& Erikson, T. (2016) Teacher Education as Transformation: Some Lessons Learned from a Center for Excellence in Education, Acta Didactica Norge, 10 (2), 53- 72.

17. Ng, W. (2012). Can we teach digital natives digital literacy? Computers \& Education, 59(3), 1065-1078.

18. Ottestad, G., Kelentrić, M., \& Guðmundsdóttir, G. B. (2014). Professional Digital Competence in Teacher Education. Nordic Journal of Digital Literacy, 9(04), 243-249. 


\section{References:}

[1] Bykov V., Leshchenko M. Tsyfrova humanistychna pedahohika vidkrytoi osvity. Teoriia i praktyka upravlinnia sotsialnymy systemamy. № 4. s. 115-130. URL: http://nbuv.gov.ua/UJRN/Tipuss_2016_4_13

[2] Henseruk H. Tsyfrova kompetentnist yak odna iz profesiino znachushchykh kompetentnostei maibutnikh uchyteliv. Open educational e-environment of modern University, № 6. 2019. s. 8-16.

[3] Zhaldak M. I., Ramskyi Yu. S., Rafalska M. V. Model systemy sotsialno-profesiinykh kompetentnostei vchytelia informatyky. Naukovyi chasopys Natsionalnoho pedahohichnoho universytetu imeni M. P. Drahomanova. Seriia 2. Kompiuterno-oriientovani systemy navchannia. № 7. 2009. s. 3-10.

[4] Morze N. V. Informatychna kompetentnist uchniv mozhe buty vyshchoiu vid kompetentnosti tykh, khto yikh navchaie? (za materialamy monitorynhovoho doslidzhennia $\mathrm{z}$ informatychnykh kompetentnostei vypusknykiv $\mathrm{v}$ Ukraini). Kompiuter u shkoli ta simi. № 8. 2010. http://nbuv.gov.ua/UJRN/komp_2010_8_2

[5] Pietukhova L. Ye. Teoretyko-metodychni zasady formuvannia informatychnykh kompetentnostei maibutnikh uchyteliv pochatkovykh klasiv (avtoref. dys. dokt. ped. nauk). URL: http://dspace.pdpu.edu.ua/bitstream/123456789/869/1/Петухова-.aref.pdf

[6] Spirin O. M. Informatsiino-komunikatsiini ta informatychni kompetentnosti yak komponenty systemy profesiino-spetsializovanykh kompetentnostei vchytelia informatyky. Informatsiini tekhnolohii i zasoby navchannia. № 5 (13). 2009. URL: https://journal.iitta.gov.ua/index.php/itlt/article/download/ 183/169

[7] Almerich, G., Orellana, N., Suárez-Rodríguez, J., \& Díaz-García, I. (2016). Teachers' information and communication technology competences: A structural approach. Computers \& Education, 100, 110-125.

[8] Erstad, O. (2015). Educating the Digital Generation. Nordic Journal of Digital Literacy, 5(01), 56-71.

[9] Ferrari, A. (2012). DIGCOMP: A Framework for Developing and Understanding Digital Competence in Europe. Luxembourg: Publications Office of the European Union.

[10] Hatlevik, O. E. (2017). Examining the Relationship between Teachers' Self-Efficacy, their Digital Competence, Strategies to Evaluate Information, and use of ICT at School. Scandinavian Journal of Educational Research, 61(5), 555-567.

[11] Ilomaki, L., Paavola, S., Lakkala, M., \& Kantosalo, A. (2016). Digital competence-an emergent boundary concept for policy and educational research. Education and Information Technologies, 21(3), 655-679.

[12] Instefjord, E. (2015). Appropriation of Digital Competence in Teacher Education. Nordic Journal of Digital Literacy, 9(04), 313-329.

[13] Johannesen, M., Øgrim, L., \& Giæver, T. H. (2014). Notion in Motion: Teachers' Digital Competence. Nordic Journal of Digital Literacy, 9(04), 300-312.

[14] Kelentrić, M., Helland, K. \& Arstorp, A. (2017) Professional digital competence framework for teachers. The Norwegian Centre for ICT in Education

[15] Krumsvik, R. J. (2014). Teacher Educators' Digital Competence. Scandinavian Journal of Educational Research, 58(3), 269-280.

[16] Lund, A. \& Erikson, T. (2016) Teacher Education as Transformation: Some Lessons Learned from a Center for Excellence in Education, Acta Didactica Norge, 10 (2), 53- 72.

[17] Ng, W. (2012). Can we teach digital natives digital literacy? Computers \& Education, 59(3), 1065-1078.

[18] Ottestad, G., Kelentrić, M., \& Guðmundsdóttir, G. B. (2014). Professional Digital Competence in Teacher Education. Nordic Journal of Digital Literacy, 9(04), 243-249.

\section{ГЕНСЕРУК Г. Р. Цифровая компетентность будущих учителей: зарубежный опыт.}

В статье рассмотрены различные подходы зарубељныьх ученых относительно трактовки понятия “иифровая компетентность” и определение составляюших компонентов цифровой компетентности будуиих спеииалистов. Проведен анализ последних работ ученых по исследуемой проблеме. Проанализированы европейские стандарты определения иџировой компетентности, рамку ицировой компетентности учителя Digital Coтреtence of Educators (DigCoтpEdu). B статье вылелены подходы к описанию составляющих рамки циирровой компетентности учителей. Цифровая компетентность будущих учителей является важной и предполагает умение логически и системно использовать ичирровые технологии. Она способствует успешности будущего специалиста, решению различных задач $u$ формированию его важных жизненных компетениий.

Анализ работ зарубежных исследователей позволяет сделать вывод о различных подходах по классификации и описания видов цифрровых компетениий учителя. Разработанные рамки цифровых 
компетенций различных стран преимущественно включают следующие составляюшие: применение циифровых технологий в профессиональном педагогической среде; владение профессиональными навыками поиска, создания и совместного использования циифрового образовательного контента; применение циифровых инструментов в обучении и преподавании; владения цифрровьли инструментами и стратегиями оченки результатов обучения; использование ичифровых инструментов для расширения образовательных возможностей учащиххя; безопасность при применении циифровых технологий.

ключевые слова: компетентность, циифровая компетентность, ичирровые технологии, рамка цичфровой компетентности, модель.

HENSERUK H. R. Digital competence of future teachers: foreign experience.

Different approaches of foreign scientists to interpret the concept of "digital competence" and identify the components of digital competence of future professionals have been discussed in the article. An analysis of the recent work of scientists on the problem has been conducted. The European standards for determining digital competence, the Digital Competence of Educators (DigCompEdu) teacher's digital competence framework have been analyzed. In the article the approaches to the description of the components of the digital competence of teachers have been highlighted. Frameworks for digital competencies in different countries have been developed. The digital competence of future teachers is important and implies the ability to use digital technology logically and systematically. It contributes to the success of the future specialist, the solution of various tasks and the formation of his important life competencies.

The list mainly includes the following components: the usage of digital technologies in a professional pedagogical environment; the mastering of the professional skills of finding, the creating and sharing digital educational content; the usage of digital tools in teaching and studying; the mastering of digital tools and strategies for evaluating learning outcomes; the usaage of digital tools to enhance students' educational opportunities; the security when using digital technologies.

Keywords: competence, digital competence, digital technologies, digital competence framework, model.

DOI: https://doi.org/10.31392/NZ-npu-144.2019.07

УДК 377.091.12.011.3-051:005.336.5

Гриженко В. В.

\section{ПЕДАГОГІЧНЕ ПРОЕКТУВАННЯ ЯК ПЕДАГОГІЧНА УМОВА РОЗВИТКУ ФАХОВИХ КОМПЕТЕНТОСТЕЙ ВИКЛАДАЧІВ ЗАКЛАДІВ ПРОФЕСІЙНО-ТЕХНІЧНОЇ ОСВІТИ}

У статті розкрито сутнісні характеристики педагогічного проектування як педагогічної умови розвитку фахових компетентостей викладачів закладів професійно-технічної освіти. Охарактеризовано особливості проектної діяльності для викладачів закладів професійно-технічної освіти. Представлено різні погляди вчених на суть досліджуваного поняття. Визначено приниипи педагогічного проектування. Доведено важливість використання технологій педагогічного проектування у професійно-технічних навчальних закладах. Виокремлено структурні компоненти педагогічного проектування.

Ключові слова: педагогічне проектування, педагогічна умова, викладач, професійно-технічна ocвima.

У контексті знаходження відповідей на виклики сучасності та, зважаючи на трансформаційні і модернізаційні зміни в сучасній системі освіти України, в професійно-технічній освіті виникають проблеми розвитку фахових компетентностей викладачів. В умовах, коли змінюється освітня стратегія, 